\title{
Myofascial Pain Syndrome in Medical Doctors
}

\section{Doktorlarda Miyofasyal Ağrı Sendromu}

\author{
Çağıl Vural ${ }^{1}$, Seçil Vural ${ }^{2}$, Tuğba Kavasoğlu ${ }^{3}$, Ahmet Onat Bermede ${ }^{4}$, Afife Ayla Kabalak ${ }^{5}$ \\ ${ }^{1}$ Ankara Numune Research And Training Hospital, Ankara \\ ${ }^{2}$ Ankara Physical Medicine Rehabilitation Research And Training Hospital, Ankara \\ ${ }^{3}$ Ankara Reserch And Training Hospital, Ankara \\ ${ }^{4}$ Ankara University Medical Faculty, Ankara \\ ${ }^{5}$ Ulus State Hospital, Ankara
}

Doi: $10.5505 /$ aot.2013.96168

\section{ÖZET}

Amaç: Bu çalışmanın amacı dahiliye uzmanları ile anestezi uzmanları arasında sırt ve boyun ağrılarını içeren miyofasyal ağrı sendromu (MAS) oluşumunu karşılaştırmaktır.

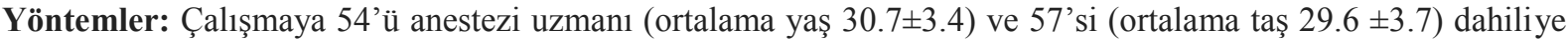
uzmanı olmak üzere toplam 111 tıp doktoru dahil edilmiştir. Her iki grup arasında demografik özellikler, risk faktörleri, Görsel Analog Skala, Nottingham Sağlık Profili ve Beck Depresyon Skalası karşılaştırılmıştır.

Bulgular: MAS anestezi uzmanlarında dahiliye uzmanlarına göre belirgin olarak daha sık bulunmuştur $(p=0.001)$. Beck Depresyon Skalası değerleri belirgin olarak daha yüksek ve Nottingham Sağlık Profili değerleri de MAS olan kişilerde belirgin olarak daha düşük bulunmuştur $(\mathrm{p}<0.001)$.

Sonuç: MAS'ın anestezi uzmanlarında, dahiliye uzmanlarına göre daha sık olduğunu söyleyebiliriz. Ek olarak, MAS yaşam kalitesini olumsuz yönde etkileyen bir parametredir. Daha iyi bir yaşam kalitesine ulaşmak için altta yatan risk faktörleri önlenmelidir.

Anahtar Kelimeler: Yaşam kalitesi; tetik nokta; ağrı; postür; depresyon; uyku bozuklukları

\begin{abstract}
Objective: The aim of this study was to compare the myofascial pain syndrome occurrence involving neck and back in anesthetist specialist with internal specialist.

Methods: A total of 111 medical doctors were included in this study. There were 54 anesthetists (a mean age of $30.7 \pm 3.4$ ) and 57 internal specialists(a mean age of 29.6 \pm 3.7 ). Demographic features, risk factors, Visual Analog Scale, Nottingham Health Profile and Beck Depression Scale were compared between the groups.

Results: MPS was significantly more frequently seen in anesthetists than internal specialists $(\mathrm{p}=0.001)$. Beck Depression Scale values were significantly higher and Nottingham Health Profile values were significantly lower in subjects with MPS (all $\mathrm{p}<0.001$ ). Moreover, sleep and posture disorders were found to be more common in subjects with MPS (all $\mathrm{p}<0.001$ ).

Conclusion: MPS is more frequently seen in anesthetists than internal specialists. Additionally, MPS is a parameter affecting the quality of life adversely. In order to achieve better quality of life, the underlying risk factors should be prevented.
\end{abstract}

Key words: Quality of life; trigger point; pain; posture; depression; sleep disorder

\section{Introduction}

Myofascial pain syndrome (MPS) is a regional musculoskeletal pain disorder characterized by trigger points. Trigger points (taut bands within the muscle/fascia) feature focal tenderness, referred pain and autonomic responses with palpation, decrement in range of motion (1). MPS usually occurs in shoulder, neck and low back muscles. MPS has been reported to be a wide and commonplace disability affecting the quality of life adversely (2).

One of the most frequently seen occupational disorders are work related musculoskeletal disorders of the upper limb and neck (2). Myofascial pain syndrome has been shown to be related to occupational factors as well. In previous data, MPS occurrence has been reported in different occupation groups (3-8). However, to our best notice, it has not been studied between medical 
doctors. Consequently, the purpose of this study was to compare the MPS occurrence in anesthetists with internal specialists and its association with the quality of life.

\section{Material-Methods}

A total of 111 medical doctors were included in this study. Demographic features, risk factors, physical examination findings of the subjects were noted. All subjects were conducted a questionnaire including risk factors for MPS. MPS was diagnosed according to Simon criteria as the follows; presence of a palpable taut band, presence of a hypersensitive tender spot, local twitch response elicited by palpation of the taut band and referred pain pattern in response to compression of the trigger point (9). Nottingham Health Profile was used to assess the quality of life of the subjects. Beck Depression Scale was used to assess the emotional condition. Informed consent was obtained from the patients and this study protocol was approved by the Local Ethics Committee.

Table 1. Demographic and Clinical Features of the Subjects

\begin{tabular}{|c|c|c|c|}
\hline Variables & $\begin{array}{l}\text { Anesthetists } \\
\text { (n: 57) }\end{array}$ & $\begin{array}{c}\text { Internal Specialists } \\
\text { (n: 54) }\end{array}$ & $p$ value \\
\hline $\begin{array}{l}\text { Age }(\text { years }) \\
\text { BMI }\left(\mathbf{k g} / \mathbf{m}^{2}\right)\end{array}$ & $\begin{array}{l}29.7 \pm 3.8 \\
23.2 \pm 3.7\end{array}$ & $\begin{array}{l}30.7 \pm 3.4 \\
22.6 \pm 3.4\end{array}$ & $\begin{array}{l}0.124 \\
0.344\end{array}$ \\
\hline Gender (n,\%) & & & 0.304 \\
\hline Male & $24(42.1 \%)$ & $28(51.9 \%)$ & \\
\hline Female & $33(57.9 \%)$ & $26(48.1 \%)$ & \\
\hline Gestation (n,\%) & $7(21.2 \%)$ & $4(15.4 \%)$ & 0.740 \\
\hline $\mathbf{D M}(\mathrm{n}, \%)$ & $4(7 \%)$ & $2(3.7 \%)$ & 0.679 \\
\hline Hypothyroidism (n,\%) & $4(7 \%)$ & - & 0.119 \\
\hline Hyperthyroidism (n,\%) & $2(3.5 \%)$ & - & 0.496 \\
\hline Exercise (n,\%) & $28(49.1 \%)$ & $36(66.7 \%)$ & 0.062 \\
\hline $\mathbf{M P S}+(\mathrm{n}, \%)$ & $19(33.3 \%)$ & $35(64.8 \%)$ & $<0.001$ \\
\hline Sedentary Life (n,\%) & $16(28.1 \%)$ & $15(27.8 \%)$ & 0.973 \\
\hline Macro Trauma (n,\%) & - & $4(7.4 \%)$ & 0.053 \\
\hline Micro Trauma (n,\%) & $6(10.5 \%)$ & $9(16.7 \%)$ & 0.344 \\
\hline Sleep Disorder (n,\%) & $16(28.1 \%)$ & $30(55.6 \%)$ & 0.003 \\
\hline Posture Disorder (n,\%) & $19(33.3 \%)$ & $24(44.4 \%)$ & 0.230 \\
\hline Beck Depression & $7(2-16)$ & $4(0-12)$ & $<0.001$ \\
\hline Nottingham Health Profile & $5.3(0-18.4)$ & $6.6(0.0-18.4)$ & 0.538 \\
\hline
\end{tabular}

The values are shown in mean \pm SD or $\mathrm{N}(\%) \mathrm{BMI}$ : Body mass index MPS: Myofascial pain syndrome 
Table 2. Comparison of the Quality of Life, Beck Depression Scale and Risk Factors in Subjects With and Without Myofascial Pain Syndrome

\begin{tabular}{|c|c|c|c|}
\hline Variables & $\begin{array}{c}\text { MPS (+) } \\
(\mathrm{n}: 54)\end{array}$ & $\begin{array}{c}\text { MPS (-) } \\
\text { (n:57) }\end{array}$ & $p$ value \\
\hline Age (Years) & $30.8 \pm 3.2$ & $29.6 \pm 3.9$ & 0,080 \\
\hline Gender & & & 0,622 \\
\hline Male & $24(44.4 \%)$ & $28(49.1 \%)$ & \\
\hline Female & $30(55.6 \%)$ & $29(50.9 \%)$ & \\
\hline Gestation & $7(23.3 \%)$ & $4(13.8 \%)$ & 0.347 \\
\hline Marital Status (n,\%) & & & 0.091 \\
\hline Single & $18(33.3 \%)$ & $28(49.1 \%)$ & \\
\hline Married & $36(66.7 \%)$ & $29(50.9 \%)$ & \\
\hline BMI $\left(\mathrm{kg} / \mathrm{m}^{2}\right)$ & $23.1 \pm 4$ & $22.8 \pm 3.3$ & 0.672 \\
\hline $\mathbf{D M}(\mathrm{n}, \%)$ & $2(3.7 \%)$ & $4(7 \%)$ & 0.679 \\
\hline Hypothyroidism (n,\%) & $2(3.7 \%)$ & $2(3.5 \%)$ & 1 \\
\hline Hyperthyroidism (n,\%) & $2(3.7 \%)$ & - & 0.234 \\
\hline Exercise (n,\%) & $41(75.9 \%)$ & $23(40.4 \%)$ & $<0.001$ \\
\hline Department $(\mathrm{n}, \%)$ & & & $<0.001$ \\
\hline Internal Specialists & $19(35.2 \%)$ & $38(66.7 \%)$ & \\
\hline Anesthetists & $35(64.8 \%)$ & $19(33.3 \%)$ & \\
\hline Sedentary Life (n,\%) & $14(25.9 \%)$ & $17(29.8 \%)$ & 0.647 \\
\hline Macro Trauma (n,\%) & $2(3.7 \%)$ & $2(3.5 \%)$ & 1 \\
\hline Micro Trauma (n,\%) & $6(11.1 \%)$ & $9(15.8 \%)$ & 0.471 \\
\hline Emotional Stress (n,\%) & $22(40.7 \%)$ & $29(50.9 \%)$ & 0.284 \\
\hline Sleep Disorder $(\mathrm{n}, \%)$ & $40(74.1 \%)$ & $6(10.5 \%)$ & $<0.001$ \\
\hline Posture Disorder (n, \%) & $32(59.3 \%)$ & $11(19.3 \%)$ & $<0.001$ \\
\hline Beck Depression Scale & $7(1-16)$ & $4(0-13)$ & $<0.001$ \\
\hline NHP & $7.9(0-18.4)$ & $2.6(0-15.8)$ & $<0.001$ \\
\hline
\end{tabular}

The values are shown in mean \pm SD or N (\%) BMI: Body mass index MPS: Myofascial pain syndrome NHP: Nottingham Health Profile

\section{Statistical Analysis}

SPSS for Windows 11.5 program was used for statistical analysis. Kolmogorov Smirnov test was used to determine if the continuous variables were normally distributed. Descriptive statistics shown as mean \pm standard deviation or median (min, max). Student's t test or Mann Whitney U test (for Adressforcorrespondence: Uzm. Dr. Çağıl Vural -mali: cagilvural@hotmail.com

Available at www.actaoncologicaturcica.com Copyright @Ankara Onkoloji Hastanesi continuous variables) and Pearson chi-square or Fisher's exact tests (for categorical variables) were used for comparing the groups, where appropriate. Mean or median values of the repetitive measurements within the each group were analyzed by using Bonferroni Correction, Multiple Comparison test and Bonferroni Correction Wilcoxon Signed Rank test, respectively. Multivariable logistic regression analysis was used to show the 
effects of the risk factors on MPS. Variables which were determined as $\mathrm{p}<0.25$ after the single variable analysis were incorporated in multivariable models. Odd's ratio and 95\% confidence interval were determined regarding each variable. A p-value of $<0.05$ was considered statistically significant.

\section{Results}

There were 54 anesthetists (a mean age of $30.7 \pm 3.4$ ) and 57 internal specialists (a mean age of 29.6 \pm 3.7 ). Clinical and demographic features of the patients were given in Table 1 . MPS was significantly more frequently seen in anesthetists than internal specialists $(\mathrm{p}=0.001)$. Comparison of the demographic features, risk factors, Nottingham Health Profile and Beck Depression Scale values of the patients with and without MPS were shown in Table 2. Beck Depression Scale and Nottingham Health Profile values were significantly higher in subjects with MPS (all $\mathrm{p}<0.001$ ). Moreover, sleep and posture disorders were found to be more common in subjects with MPS (all $\mathrm{p}<0.001)$. Logistic regression analysis with respect to the effects of the risk factors on myofascial pain syndrome shown in Table 3.

\section{Discussion}

In present study, we aimed to compare the MPS occurrence in anesthetists and internal specialists and we would like to determine if there was any association between MPS and quality of life.

According to our results; MPS occurrence was significantly higher in anesthetists. When compared the parameters in subjects with and without MPS; Beck Depression Scale, sleep and posture disorders values were significantly higher and the quality of life was significantly worse in subjects with MPS.

Mechanic factors (inappropriate posture, prolonged immobility, constitutional asymmetries, micro/macro trauma), psychosocial factors, sleep disorders, nutrition insufficiency, metabolic/endocrinological disorders have been shown to be underlying mechanisms in MPS ethiopathogenesis $(3,10)$. Nonetheless, musculoskeletal disorders are in association with work conditions -work environment, procedures, equipment and socio-psychological factors- and they may cause difficulties not only in activities of daily living but also in performing occupational tasks (11). Likewise, in our study, MPS was commonplace in anesthetists probably due to working in harder conditions than internal specialists, low temperature due to air conditi-

Table 3. Logistic Regression Analysis With Respect to the Effects of the Risk Factors on Myofascial Pain Syndrome

\begin{tabular}{|c|c|c|c|c|}
\hline \multirow[t]{2}{*}{ Variables } & \multirow[t]{2}{*}{ Odd's Ratio } & \multicolumn{2}{|c|}{$\% 95$ Confidence Interval } & \multirow[t]{2}{*}{$p$ value } \\
\hline & & Lower Limit & Upper Limit & \\
\hline Surgeons & 14.808 & 2.278 & 96.275 & 0.005 \\
\hline Age & 1.184 & 0.968 & 1.448 & 0.099 \\
\hline Exercise & 0.213 & 0.050 & 0.913 & 0.037 \\
\hline Beck Depression & 1.405 & 1.090 & 1.810 & 0.009 \\
\hline Sleep Disorder & 21.850 & 2.373 & 201.209 & 0.006 \\
\hline Posture Disorder & 1.003 & 0.097 & 10.365 & 0.998 \\
\hline
\end{tabular}

NHP: Nottingham Health Profile

oner in operating rooms, standing in inappropriate posture for long time periods, being stressed because of the risky operations, sleeplessness for long periods and fatigue. In the light of our results, being an anesthetist, sleeping disorder, posture disorder and emotional status were found as risk factors.

All the aforementioned factors can easily be preventable. In the previous data, concerning the elimination of the risk factors, working ergonomics have been shown 
effective for the management of musculoskeletal disorders (12-15).

We have some limitations in our study. We carried out a cross-sectional study and evaluated only neck and back region. Moreover, the sample size could be more concerning the detailed clinical parameters.

In the light of our first and preliminary results, we found that MPS is more frequently seen in anesthetists than internal specialists. Additionally, MPS is a parameter affecting the quality of life adversely. In order to achieve better quality of life, the underlying risk factors should be eliminated. Therefore, adequate ergonomic design and prevention strategies are of paramount importance. Further studies with long term follow-up including intervention and prevention strategies are awaited.

\section{Conflict of interest: None}

\section{References}

1. Brimmer DJ, McCleary KK, Lupton TA, Faryna KM, Reeves WC. Continuing medical education challenges in chronic fatigue syndrome. BMC Med Educ 2009;9:70

2. Hoe VC, Urquhart DM, Kelsall HL, Sim MR. Ergonomic design and training for preventing workrelated musculoskeletal disorders of the upper limb and neck in adults. Cochrane Database Syst Rev 2012;8:CD008570

3. Walker-Bone K, Palmer KT. Musculoskeletal disorders in farmers and farm workers. Occup Med (Lond) 2002;52:441-50

4. Treaster D, Marras WS, Burr D, Sheedy JE, Hart D. Myofascial trigger point development from visual and postural stressors during computer work. J Electromyogr Kinesiol 2006;16:115-24
5. Dryson EW, Walls CB. The distribution of occupations in two populations with upper limb pain. Int J Occup Environ Health 2001;7:201-5

6. Waylonis GW, Ronan PG, Gordon C. A profile of fibromyalgia in occupational environments. Am J Phys Med Rehabil 1994;73:112-5

7. Bryant GW. Myofascial pain dysfunction and viola playing. Br Dent J 1989;166:335-6

8. Hoyle JA, Marras WS, Sheedy JE, Hart DE. Effects of postural and visual stressors on myofascial trigger point development and motor unit rotation during computer work. J Electromyogr Kinesiol 2011;21:418

9. Simons DG, Travell JG, Simons LS. General Overview. In: Johnson EP, eds. Myofascial Pain and Dysfunction: The Trigger Point Manual. Second ed. Baltimore: Williams \& Wilkins, 1999:11-89.

10. Cummings M, Baldry P. Regional myofascial pain: diagnosis and management. Best Pract Res Clin Rheumatol 2007;21:367-87

11. Choi K, Park JH, Cheong HK. Prevalence of musculoskeletal symptoms related with activities of daily living and contributing factors in Korean adults. J Prev Med Public Health 2013;46:39-49

12. Van Niekerk SM, Louw QA, Hillier S. The effectiveness of a chair intervention in the workplace to reduce musculoskeletal symptoms. A systematic review. BMC Musculoskelet Disord 2012;13:145

13. Pillastrini P, Mugnai R, Bertozzi L, et al. Effectiveness of an ergonomic intervention on workrelated posture and low back pain in video display terminal operators: a 3 year cross-over trial. Appl Ergon 2010;41:436-43

14. Robertson MM, Amick BC, DeRango K et al. The effects of an office ergonomics training and chair intervention on worker knowledge, behavior and musculoskeletal risk. Appl Ergon 2009;40:124-3

15. Amick BC, Robertson M, DeRango K et al. The effect of an office ergonomics intervention on reducing musculoskeletal symptoms. Spine 2003;28:2706-71 